\title{
Breakdown of Cellulose by Yeast Species
}

\author{
By C. DENNIS \\ A.R.C. Food Research Institute, Colney Lane, Norwich, NOR $70 F$
}

(Accepted for publication Io February 1972)

Yeasts as defined by Lodder (1970) are collectively capable of utilizing many different substrates, including mono-, di-, and trisaccharides, polyols, ethanol and organic acids. Some yeasts are capable of utilizing polysaccharides, but the attack is usually limited to soluble starch, inulin, and more rarely pectin (Luh \& Phaff, I95I ; Bell \& Etchells, 1956; Wieringa, 1956; Ingram, 1958), and as far as the author is aware there are no previous reports of yeasts attacking cellulose (cf. Ingram, I958; Do Carmo-Sousa, I969). This communication reports cellulolytic activity by Trichosporon species.

During an investigation of the microbial flora of forced rhubarb (Rheum rhaponticum var. Timperly Early and var. Early Victoria) Trichosporon cutaneum was isolated from freshly harvested petioles and leaf blades in numbers up to $2.5 \times 10^{3}$ and $3.5 \times 10^{4}$ per $\mathrm{g}$ respectively. This yeast was also frequently isolated from the leading edge of rotted areas of petioles, sometimes in association with pectolytic bacteria. Inoculation of surface-sterilized cut petioles of rhubarb with $T$. cutaneum isolates confirmed that this yeast could act as a primary invader. Pectin and cellulose are the main constituents of plant cell walls, hence the ability of these isolates to degrade these substances was examined.

Pectin breakdown was tested by growing the yeasts on yeast extract-glucose-peptonemalt extract agar (Wickerham, I95I), containing $0.5 \%$ calcium chloride, overlayered with $2 \%$ sodium polypectate. All the isolates of Trichosporon cutaneum degraded pectate as shown by the formation of craters around the colonies. Isolates of $T$. pullulans, Cryptococcus macerans and $C$. albidus var. albidus also were observed to degrade pectate. This is contrary to the findings of Di Menna (1959).

Cellulose breakdown was tested by the method used by Bravery (1968) to demonstrate the cellulolytic activity by soft-rotting fungi of wood. The mineral salts-cellulose media (media I and VII - see Bravery, I968) were used except that the concentration of cellulose (ball-milled Whatman no. I filter paper) was reduced to $0.5 \%$. Incubation was at $20^{\circ} \mathrm{C}$ for 3 weeks. Cellulolytic activity was indicated by the appearance of clear zones around the yeast colonies in the opaque cellulose media.

Nine out of 12 strains of Trichosporon cutaneum and 12 out of 13 strains of $T$. pullulans showed cellulolytic activity. The most active strains showed this activity after 6 to 7 days of incubation at $20^{\circ} \mathrm{C}$. The presence of small amounts of yeast extract $(0.5 \mathrm{mg} / \mathrm{ml})$ and asparagine $(0.5 \mathrm{mg} / \mathrm{ml})$ stimulated cellulolytic activity in some of the isolates of $T$. cutaneum and $T$. pullulans but reduced and/or delayed activity in others.

Levinson, Mandels \& Reese (I95I) reported cellobiose to be the main end-product of cellulose hydrolysis by the mould Trichoderma viride. Yeasts, other than Trichosporon species, and the yeast-like organism Aureobasidium pullulans, all of which can utilize cellobiose as sole carbon source, were therefore assayed for cellulolytic activity. With the same test no cellulolytic activity was observed with ten strains of $A$. pullulans, three strains of Torulopsis fragaria, two strains of Kloeckera apiculata and single strains of Cryptococcus 
laurentii, C. laurentii var. flavescens, C. diffluens, C. albidus, Torulopsis candida, Hansenula anomala, $H$. saturnus, $H$. silvicola, Pichia pinus, $P$. etchellsii, Endomyces capsularis, Debaryomyces hansenii and Saccharomycodes ludwigii. The inability of $A$. pullulans to degrade cellulose is in agreement with previous work (White, Darby, Stechert \& Sanderson, I948).

The cellulase activity of two strongly cellulolytic strains (on the basis of plate clearing) of each of Trichosporon cutaneum and T. pullulans was studied further. The ability to attack a less degraded form of cellulose was tested with Whatman no. I filter-paper discs, $5.5 \mathrm{~cm}$ in diameter. The strains were grown in shaken liquid culture on media I and VII (without agar) at $20^{\circ} \mathrm{C}$ on a gyratory shaker (200 rev/min). Degradation of the filter-paper cellulose was visible after 7 days of shaking at $20^{\circ} \mathrm{C}$. The filter-paper discs were completely macerated after I4 days of incubation, when up to a $10 \%$ loss in dry weight was determined by filtering off the residual cellulose.

\section{Table I. Release of reducing sugars from cellulose by a culture filtrate of Trichosporon cutaneum}

Reaction mixture consisted of $2 \mathrm{ml}$ culture filtrate plus $8 \mathrm{ml}$ of $\mathrm{I} \%$ cellulose substrate in $\mathrm{NaOH} /$ succinic acid buffer pH 5.0 (see Reese, Siu \& Levinson, 1950). Culture filtrate from T. cutaneum (strain $\mathrm{YI}_{\mathrm{I}}$ ) grown on medium I for $\mathrm{I} 4$ days at $20^{\circ} \mathrm{C}$.

Total reducing sugar was estimated on I ml. samples by the Somogyi-Nelson method (Whistler \& Wolfrom, 1962). Samples taken at time o were used as blanks. The Boehringer Blood Sugar GOD. Perid-Method was used for estimating glucose. The protein content of the filtrate $(\mathrm{I} 28 \mu \mathrm{g} / \mathrm{ml})$ was estimated by the Folin-phenol method of Lowry, Rosebrough, Farr \& Randall (I95I), after dialysis against distilled water at $2{ }^{\circ} \mathrm{C}$ for $24 \mathrm{~h}$. Bovine plasma albumen was used as a standard.

Carboxymethylcellulose (sodium salt, low viscosity)

\begin{tabular}{ccc}
\hline $\begin{array}{c}\text { Time } \\
(\mathrm{h})\end{array}$ & $\begin{array}{c}\text { Total reducing } \\
\text { sugar* }(\mu \mathrm{g} / \mathrm{ml})\end{array}$ & $\begin{array}{c}\text { Glucose } \\
(\mu \mathrm{g} / \mathrm{ml})\end{array}$ \\
2 & $4 \cdot 0$ & $3 \cdot 0$ \\
4 & $13 \cdot 0$ & $8 \cdot 0$ \\
6 & $44 \cdot 0$ & $14 \cdot 0$ \\
24 & $94 \cdot 0$ & $13 \cdot 0$
\end{tabular}

Ball-milled Whatman no. I filter-paper cellulose

* Expressed as equivalent glucose.

$\begin{array}{ccc}\begin{array}{c}\text { Time } \\ (\mathrm{h})\end{array} & \begin{array}{c}\text { Total reducing } \\ \text { sugar* }(\mu \mathrm{g} / \mathrm{ml})\end{array} & \begin{array}{c}\text { Glucose } \\ (\mu \mathrm{g} / \mathrm{ml})\end{array} \\ 6 & 10 \cdot 0 & 9 \cdot 0 \\ 24 & 32 \cdot 0 & 21 \cdot 0 \\ 30 & 82 \cdot 0 & 29 \cdot 0 \\ 48 & 132 & 34 \cdot 0\end{array}$

The presence of cellulase in culture filtrates was shown by filling a well, cut in an agar plate containing $0.25 \%$ ball-milled filter-paper cellulose, with filtrate. After $48 \mathrm{~h}$ at $20^{\circ} \mathrm{C}$ the clearing zones around the well were recorded.

When culture filtrates were incubated with ball-milled filter-paper cellulose on carboxymethyl cellulose, reducing sugars were released (Table I). In both cases most of the reducing sugar in the early stages could be accounted for as glucose. Thereafter, there was little increase in release of glucose, although total reducing sugar continued to increase. Examination of the hydrolysate by paper chromatography, as described by Levinson et al. (I95I), showed that cellobiose was the only other reducing sugar detected.

The glucose released was less than $\mathrm{I} \%$ of the theoretical maximum. This yield is relatively low, but the conditions used were not necessarily optimal for production or activity of cellulase. Katz \& Reese (1968) suggest a $5 \%$ yield as more usual with other fungal enzymes, though a value as high as $30 \%$ has been observed with Trichoderma viride cellulase.

Cellulase production appeared to be restricted to Trichosporon species and therefore may be of use in yeast identification and classification. However, most of the yeasts used here, other than Trichosporon cutaneum had been maintained in culture for at least a year on media lacking cellulose, and it is possible that cellulolytic activity may have been lost under 
these circumstances. Similarly, strain differences may account for the discrepancy between the present observations and those of Di Menna with regard to pectolytic activity.

The author thanks R. W. Buhagiar for identifying some of the isolates of Trichosporon cutaneum, T. pullulans and Cryptococcus macerans, and Miss M. E. Flegg for technical assistance.

\section{REFERENCES}

Bell, T. A. \& Etchells, J. L. (1956). Pectin hydrolysis by salt-tolerant yeasts. Applied Microbiology 4, I96201 .

BRAVERY, A. F. (I968). Microbiological breakdown of cellulose in the presence of alternative carbon sources. Journal of Science Food and Agriculture 19, I33-135.

Di MENNA, M. E. (1959). Some physiological characters of yeasts from soils and allied habitats. Journal of General Microbiology 20, 13-23.

Do Carmo-Sousa L. (1969). In The Yeasts, vol. I, p. 79. Edited by A. H. Rose \& J. S. Harrison. London \& New York: Academic Press.

IngRam, M. (1958). In Chemistry and Biology of Yeasts, p. 603. Edited by A. H. Cook. London \& New York: Academic Press.

KaTZ, M. \& ReESE, E. T. (I968). Production of glucose by enzymatic hydrolysis of cellulose. Applied Microbiology 16, 419-420.

Levinson, M. S. Mandels, G. R. \& Reese, E. T. (195I). Products of enzymatic hydrolysis of cellulose and its derivatives. Archives of Biochemistry and Biophysics 31, 35I-365.

Lodder, J. (1970). The Yeasts. Amsterdam: North Holland Publishing Co.

Lowry, O. H., Rosebrough, J. N., Farr, A. L. \& Randall, R. J. (1951). Protein measurement with the Folin phenol reagent. Journal of Biological Chemistry 193, 265-275.

LuH, B. S. \& PhafF, M. J. (195I). Studies on polygalacturonase of certain yeasts. Archives of Biochemistry and Biophysics 33, $212-227$.

Reese, E. T., Siv, R. G. H., \& Levinson, H. S. (1950). The biological degradation of soluble cellulose derivatives and its relationship to the mechanism of cellulose hydrolysis. Journal of Bacteriology 59, 485497.

Whistler, R. L. \& Wolfrom, M. L. (1962). Methods in Carbohydrate Chemistry, vol. I, p. 386. London: Academic Press.

White, W. L., Darby, R. T., Stechert, G. M. \& Sanderson, K. (I948). Assay of cellulolytic activity of moulds isolated from fabrics and related items exposed in the tropics. Mycologia 40, 34-84.

Wickerham, L. J. (195I). Taxonomy of yeasts. Technical Bulletin of the United States Department of Agriculture no. 1029.

WIERINGA, K. T. (1956). The micro-organisms decomposing pectic substances in the dew retting process of flax. Netherlands Journal of Agricultural Science 4, 204-209. 